\title{
PUBLIC HEALTH AND THE NEW LAW OF PUBLIC HEALTH IN REPUBLIC OF SERBIA
}

Nela Djonovic ${ }^{1,2}$, Ivana Simic Vukomanovic ${ }^{2}$, Dalibor Stajic ${ }^{1}$

${ }^{1}$ Department of Hygiene and ecology, Faculty of Medical Sciences, University of Kragujevac,Kragujevac, Serbia ${ }^{2}$ Institute of Public Health Kragujevac, Serbia

\author{
JAVNO (NARODNO) ZDRAVLJE I NOV ZAKON O \\ JAVNOM (NARODNOM) ZDRAVLJU U REPUBLICI SRBIJI \\ Nela Đonović1,2, Ivana Simić Vukomanović ${ }^{2}$, Dalibor Stajić ${ }^{1}$ \\ ${ }^{1}$ Katedra za higijenu i ekologiju, Fakultet medicinskih nauka, Univerzitet u Kragujevcu, Kragujevac, Srbija \\ ${ }^{2}$ Institut za javno zdravlje Kragujevac, Srbija
}

\begin{abstract}
The new Law on Public Health was published in the Official Gazette of the Republic of Serbia No. 15 dated 25 February 2016. Comparing to the previous Law, the biggest changes have been made in the domain of monitoring the indicators of the environment and population health. The responsibility of controlling the quality and safety of food was given back to the Ministry of Health. This paper presents the principal regulations regarding the main functions, principals and organizational features of the public health system in Serbia.
\end{abstract}

Keywords: Public Health, New Legislation, Health System, Serbia, Health Policy

\section{SAŽETAK}

Novi Zakon o javnom zdravlju objavljen je u Službenom glasniku Republike Srbije br. 15 od 25.02.2016.godine. Osnovne promene u odnosu na stari zakon se odnose na praćenje indikatora životne sredine i njihovom uticaju na zdravlje stanovništva. Odgovornost za kontrolu kvaliteta i bezbednosti hrane je ovim zakonom vraćena u domen rada Ministarstva zdravlja. Ovaj Zakon trebalo bi da unapredi nivo zdravstvene zaštite gradana kao $i$ da aktivno radi na očuvanju i unapređenju zdravlja stanovništva. U ovom radu su prikazane osnovne regulativne norme koje se tiču glavnih funkcija, principa i organizacionih osobina sistema javnog zdravlja u Srbiji.

Ključne reči: zakon, javno (narodno) zdravlje

\section{INRODUCTION}

A law on public health is one of the most important legal acts in the health sector. Health is the main resource of every individual and society as a whole. Along with developing curative methods and techniques, modern medicine also developes methods of prevention. A large number of developed countries allocate significant resources to the development of public health (1-5).

The new Law on Public Health was published in the Official Gazette of the Republic of Serbia No. 15 dated 25 February 2016 (6). As in the previous law, it has been established that all programs of public health should be implemented and actively participated by the health service networks - primarily the Institutes (led by the National Institute of Public Health of Serbia), health and social insurance, and the broader community (including state authorities and ministries, educational and other institutions, public companies, the Red Cross of Serbia, churches and religious communities, citizens, local authorities etc.) (7). Based on the results of studies on the health status of the relevant population, Institutes actively participate not only in the preservation and improvement of human health, but also in establishing the current health policy (8). This Act should enhance the level of health protection of citizens and preserve and improve their health condition $(6,7)$.

The Law has stipulated that social care should include the policy and the strategy of public health, monitoring the health status of the population, identification of health problems, determination of the main tasks, the adoption of special programs in the field of public health, implementation of tax measures and economic policies that encourage healthy lifestyles, providing conditions for health care and education of the population and the conditions for rapid

\section{Sciendo


and adequate response in emergency situations. The main changes have been made in the domain of monitoring the indicators of the environment and population health. Public health departments and institutes have taken the responsibility of controlling the state of the environment, the quality and safety of drinking water, food and objects of general use. They are also in charge of monitoring the hygiene standards in health care facilities, schools and kindergartens, sport facilities, facilities where food is produced, processed, distributed and sold etc. The health care institutions should estimate the health risks to the population, based on the register of polluters, and they should monitor and analyse the population health based on the state of the environment. The assessment of the epidemiological situation is also under the competency of these institutions. The important thing is that monitoring of food quality has been brought back under the jurisdiction of the Ministry of Health (6).

\section{A DEFINITION OF PUBLIC HEALTH}

Concepts and definitions of public health are quite voluminous and complex in all countries with rather developed or intensively developing public health. Most of these definitions are based on the concepts of preserving and improving health of population (9). According to the World Health Organization, "Public health is a social and political action that aims to improve health, extend life and improve its quality in the entire population through health promotion, disease prevention and other forms of medical intervention" (1).

\section{THE HISTORY}

Social care for health was developing along with the first medical skills, so that some of its roots could be found even in the ancient Egyptian and Greek medicine. During the historical development, the concepts of public health have undergone significant changes. Historically, the development of public health can be divided into four periods:

1. the period of hygienic sanitation;

2. the period of individual health care;

3. the period of therapeutic procedures;

4. the new public health period.

The development of public health and organized health care in our country began in 1839, with the adoption of the first Constitution that enabled foundation of a quarantine ward and an ambulance with the task "to do all that can serve to protect the life and health of people". At the beginning of the twentieth century and with the opening of the first medical school in Belgrade, health institutions were established and they performed public health services (The Central Hygiene Institute in Belgrade) $(10,11)$.

\section{THE MAIN PRINCIPLES OF PUBLIC HEALTH}

The main principles of public health are: equality and solidarity, sustainability, participation, efficiency, justice and peace. The main principle of the new public health is to connect the traditional goals of public health with the work of institutions involved in the individual health protection and social activities $(12,13)$.

Modern human activities and lifestyles have brought new challenges in the field of public health, including new techniques and weapons of mass destruction (terrorism, particularly bioterrorism) (14), emergency situations (especially natural disasters like earthquakes, floods, volcanic eruptions, hurricanes, tsunami etc.) (15), some new infectious diseases (SARS, "bird flu", "swine flu") (16) and old diseases with a large number of newly infected people (such as tuberculosis), increasing resistance of microorganisms to antibiotics and disinfectants (17), expansion of chronic diseases on a global scale (depression, obesity etc.) (18), diseases associated with unhealthy habits (e.g. smoking) (19), and many others (20). The conditions of modern life induce new threats to population health, such as globalization, the collapse of public health infrastructure, poverty and hunger in the world, wars, mass migrations, etc (21). Modern medicine can not be imagined without the public health achievements such as vaccination programs, the safety of drinking water, food and objects of general use, the safety at workplaces, health risk assessment, control and combating infectious diseases, reducing mortality from chronic noncommunicable diseases, family planning, improving the health of mothers and babies, recognition of tobacco use as a health hazard, improving the health care system, etc (22).

\section{FUNCTIONS OF PUBLIC HEALTH}

Functions of public health are numerous and quite demanding. They include:

1. Monitoring, evaluation and analysis of population health;

2. The public health surveillance, investigation and control of risks and threats to health;

3. Improving health of the population;

4. Social participation in all aspects of health care;

5. Development of policies and institutional capacities for planning and managing in the public health sector;

6. Improving the institutional capacities for planning and managing in the public health sector;

7. Evaluation and promotion of equitable access to necessary health services;

8. Human resource development and training in the area of public health;

9. Ensuring the quality of health care and the orientation towards an individual and population;

10. Public health survey;

11. Reducing emergencies and disasters by prevention, migration, readiness for response and rehabilitation;

12. The assessment of public health risks $(1,6,12)$. 


\section{THE ORGANIZATION OF PUBLIC HEALTH IN THE REPUBLIC OF SERBIA}

Public health care in Serbia is organized at several levels. The first level includes:

1. The Ministry of Health;

2. Other Ministries: the Ministry of labour, employment, veteran and social affairs; the Ministry of education, science and technological development, the Ministry of agriculture and environmental protection etc.

3. Inspection bodies (health and sanitary inspection bodies, market and veterinary inspection bodies, etc.);

4. The Institute of Public Health of Serbia "Dr Milan Jovanovic Batut" with the network of other institutes;

5. Community Health Centres;

The second (local) level of the organization includes:

6. Educational institutions - universities, higher and secondary medical schools, primary schools and preschool institutions;

7. Institutions of Social Protection;

8. Municipalities and local authorities;

The third level includes non-governmental sector:

9. The non-governmental organizations such as the Red Cross (1).

\section{THE LEGAL REGULATIONS}

The Republic of Serbia began with the adoption and implementation of the first legal document related to public health at the beginning of $21^{\text {th }}$ century. The first document entitled "The Health Policy of the Republic of Serbia" was adopted in 2002, based on the premise that health of people was a question of general public interest and the most important resource for development. Thereafter, the health care started to develope in accordance with the European Union strategy in this field (23).

The Ministry of Health is responsible for the organization of the public health system in the Republic of Serbia. A part of the responsibility is attributed to the other ministries, including those responsible for education, environment, social affairs, science, sports, agriculture, economy etc. The Regulation on Health Institutions' Network Plan ( "Official Gazette of RS", no. 42/06, $119 / 07$ and 84/08) has defined the institutions that make up the public health system. Twenty three institutes were established in the domain of public health. Their task is to coordinate the entire area of public health, and to directly participate in health promotion, disease prevention and environmental protection. Community health centers also have an important role in the public health system in the corresponding teritorries. The community health centers' network in Serbia consists of 160 institutions. The public health system also includes the inspection services (related to health care, sanitary surveillance, utilities, market and veterinary care) as well as the institutions in the field of education and social welfare (6-8).

Public health promotion can be performed by the organizations whose activities must be coordinated with the official policy of public health and regulated by the current legislation (13). Public health is regulated by a number of laws and regulations (the Act on Public Health, Public Health Strategy, Youth Strategy, etc.) $(20,22)$, and is funded by different sources: the funds of the Republic Institute for Health Insurance, Republic of Serbia budget and the budgets of local authorities $(24,25)$.

\section{PUBLIC HEALTH IN EUROPE}

The European Union public health policy is a part of the jurisdiction of the Health Council of the European Union. The new public health program was established in June 2002 and it has been evaluated and modernized in every 5 years (26). The program activities are under the competence of the Commission of the Health Council of the European Union (27). The program that was implemented during the period of 2003-2008 reffered to the main objectives of the new public health:

1. increasing the information and knowledge in the field of public health;

2. enabling rapid reaction and response to all health hazards;

3. determination of the major determinants of health in order to reduce mortality and prolong the life expectancy of the population.

The next program was defined for the period of 20072013. Besides the main objectives, the public health priorities of the Commission of the EU Health Council were also: 1. increasing the efficiency and responsibility in the provision of health services;

2. helping the countries in preventing diseases in order to extend the life expectancy of the active-aged population;

3. the promotion of the cooperation among the health systems of the member states and the dissemination of knowledge in the field of public health (28).

European countries have different models of public health systems (29). However, a common feature are the national public health institutes that have particularly important roles, tasks and responsibilities (30).

\section{REFERENCES:}

1. Simić $\mathrm{S}$ i ostali. Socijalna medicina. Beograd: Medicinski fakultet Univerziteta u Beogradu; 2012. 385-458.

2. Jakovljevic M. B. Resource allocation strategies in Southeastern European health policy. The European Journal of Health Economics, 2013; 14(2): 153-159. 
3. Jakovljevic M, Getzen T. Growth of Global Health Spending Share in Low and Middle Income Countries, Frontiers in Pharmacology 2016, Front. Pharmacol. doi: 10.3389/fphar.2016.00021

4. Jakovljevic MB,.Health Expenditure Dynamics in Serbia 1995-2012, Hospital Pharmacology. International Multidisciplinary Journal 2014; 1(3):180-183 UDC: 614(497.11)"1995/2012 pp/ 180-183.

5. Jakovljevic MB. BRIC's growing share of global health spending and their diverging pathways. Front. Public Health 2015; 3:135. DOI: 10.3389/fpubh.2015.00135

6. Zakon o javnom zdravlju.Službeni glasnik RS,br.15/2016

7. Zakon o javnom zdravlju.Službeni glasnik RS,br.72/2009

8. Strategija javnog zdravlja Republike Srbije. Službeni glasnik RS,br.22/2009

9. Wiskow C, Ruseva M, Laaser U. Ten years onwards: Comparison of the South Eastern European regional public health strategy 2004 and the South Eastern European 2020 strategy. SEEJPH 2016; Vol. 5. DOI 10.4119/ UNIBI/SEEJPH-2016-90

10. Pencheon D, Guest C, Meltzer D, Gray JAM.Oxford Handbook of Public Health Practice. 2nd ed.OxfordNew York: Oxford University Press; 2008. ISBN-13: 978-0199586301, ISBN-10: 0199586306

11. Šantrić-Milićević, M., \& Simić, S. Health workforce in Serbia in two periods: before and after 1950. Medicinski pregled 2009; 62(7-8): 379-383.

12. WHO. New challenges for public health, Report an interregional meeting. Geneva:WHO;1996:2. apps.who. int/iris/bitstream/10665/63061/1/WHO_HRH_96.4.pdf

13. Oxford textbook of Global Public Health. 6th Ed. Oxford University: Oxford University Press; Feb 2015. ISBN-13:9780199661756

14. Arnold, J. L., Örtenwall, P., Birnbaum, M. L., Sundnes, K. O., Aggrawal, A., Arantharaman, V., ... \& Vega, F. C. A proposed universal medical and public health definition of terrorism. Prehospital and disaster medicine 2003;18(02): 47-52.

15. Watson, J. T., Gayer, M., \& Connolly, M. A. Epidemics after natural disasters. Emerging infectious diseases 2007; 13(1): 1 .

16. National Center for Infectious Diseases (US). Addressing emerging infectious disease threats: a prevention strategy for the United States. Centers for Disease Control and Prevention; 1994.

17. Wise, R., Hart, T., Cars, O., Streulens, M., Helmuth, R., Huovinen, P., \& Sprenger, M. Antimicrobial resistance is a major threat to public health. British medical journal 1998; 317(7159): 609-611.
18. Jakovljevic M, Milovanovic O. Growing burden of non-communicable diseases in the emerging health markets: the case of BRICS; Research Topic: Health Care Financing and Affordability in the Emerging Global Markets, Front. Public Health 2015; 3:65. DOI: 10.3389/fpubh.2015.00065

19. Eriksen, M., Mackay, J., \& Ross, H. The tobacco atlas. 4th ed. Atlanta. American Cancer Society; 2013. ISBN 9781604430936

20. Vlada Republike Srbije. Nacionalni milenijumski ciljevi razvoja u Republici Srbiji. Beograd:Vlada Republike Srbije; 2006.

21. Jakovljevic M, Groot W, Souliotis K. Health care financing and affordability in the emerging global markets. Frontiers in Public Health; January 2016. DOI: 10.3389/fpubh.2016.00002

22. Ministarstvo zdravlja Republike Srbije. Strategija za razvoj i zdravlje mladih u Republici Srbiji. Beograd: Ministarstvo zdravlja Republike Srbije; 2006.

23. Jakovljevic M, Jovanovic M, Lazic Z, Jakovljevic V, Djukic A, Velickovic R, Antunovic M. Current efforts and proposals to reduce healthcare costs in Serbia. Ser J Exp Clin Res 2011; 12 (4): 161-163.

24. Krstić G. i dr. Napredak u realizaciji milenijumskih ciljeva u Republici Srbiji, Beograd: UNDP, 2010.

25. Jakovljevic MB. Health Expenditure Dynamics in Serbia 1995-2012. Hospital Pharmacology. International Multidisciplinary Journal 2014; 1(3):180-183 UDC: 614(497.11)"1995/2012 pp/ 180-183.

26. Minder, A., et al. Health Care Systems in Transition: Switzerland, Copenhagen: WHO Regional Office for Europe on behalf of the European Observatory on Health Systems and Policies 2000; 1-76.

27. Anell, A., Glenngård, A.H., Merkur, S. Sweden. Health Systems in Transition. Health System Review 2012; 14(5):1-161.

28. OECD. OECD Health Data 2015. http://www.oecdilibrary.org/social-issues-migration-health/healthat-a-glance-2015/summary/english_47801564en?isSummaryOf $=/$ content/book/health_glance-2015-en

29. Resnicow, K., Baranowski, T., Ahluwalia, J. S., \& Braithwaite, R. L. Cultural sensitivity in public health: defined and demystified. Ethnicity \& disease 1998; 9(1): 10-21.

30. Djonović N. Vladina politika i ciljevi u domenu javnog zdravlja. In Mihajlo Jakovljević (Eds.), Zdravstvena ekonomija sa farmakoekonomijom. Kragujevac: Fakultet medicinskih nauka Univerziteta u Kragujevcu 2014; 31-42. ISBN 978-86-7760-082-2. 